\title{
DRUG ANALYSIS IN NECROPHAGOUS FLIES AND HUMAN TISSUES*
}

\author{
Marija DEFINIS-GOJANOVIĆ ${ }^{1}$, Davorka SUTLOVIĆ ${ }^{1}$, Dolores BRITVIĆ ${ }^{1}$, and Bože KOKAN² \\ Split University Hospital and School of Medicine ${ }^{1}$, Natural History Museum², Split, Croatia
}

Received in December 2006

Accepted in April 2007

\begin{abstract}
Necrophagous insects may provide useful information about the time, place and cause of death. In addition, they can serve as reliable alternative specimens for toxicological analysis in cases where human tissue and fluids, normally taken during autopsies, are not available, due to decomposition of the corpse. This paper reports the results of drug analysis of the larvae of two fly families, Calliphoridae and Sarcophagidae, collected from the body of a middle-aged man who had committed suicide approximately three weeks before his corpse was found. Multiple samples of decomposed human tissue, of the blowfly, and of the larval flesh were analysed using gas chromatography/mass spectrometry (GC/MS), and amphetamine was detected in all samples. While the screening results were beyond doubt, the quantitative analysis was less clear, and further research is needed in this area.
\end{abstract}

KEY WORDS: amphetamines, entomotoxicology, forensic medicine, GC/MS

The most common application of entomological evidence in forensic medicine is the estimation of the time of death, that is, of the decomposing interval. There are additional applications which include determination of the place of death or detection of an ante mortem trauma (1). Furthermore, insects may serve as important alternative species for toxicological analysis in cases where human samples are not available for this purpose (2). Common species are the true flies or Diptera of families Calliphoridae (blowflies), Sarcophagidae (flesh flies), and Muscidae (house flies). They are highly motile, strong-flying insects, and are typically the first to reach the dead body, often within minutes of death (3). Adult flies begin to lay eggs immediately (oviposit) or deposit first-instar larvae (larviposit) or feed on various proteinrich fluids seeping from the body and then begin to oviposit (2). Several publications have described the detection of toxic and controlled substances through analyses of arthropods, including different drugs (2-4). Some studies have sought to correlate drug concentrations in human tissues with those found in Diptera larvae feeding on these tissues (5). Toxicological analyses used for insect materials are generally the same as those used for human tissues and fluids.

This study reports the results of drug analyses in the samples of two fly species (Calliphoridae and Sarcophagidae) collected from several sites on and in the body of a middle-aged man who had committed suicide approximately three weeks before his corpse was found. This analysis is the first performed in Croatia where forensic entomology has only started to develop (6). 


\section{CASE HISTORY}

The body of a 43-year-old man with a history of psychiatric disorder was found in his flat on 31 October 2005. The body way lying on the bed, uncovered, and the windows were closed. A knife was in his right hand. According to police report, the probable time of death was about 10 October 2005. The cadaver was thus almost one month old and in the initial stage of putrefaction. The larvae were found on and beside the body. At autopsy, stab wounds of the chest were established as the cause of death, and the manner of death was determined to be suicide. Numerous larval stages were also observed inside the body, especially inside the wounds.

\section{MATERIAL AND METHODS}

The larvae were collected for toxicological analysis from the skin surface and from inside the body. Several samples of human tissues and fluids (blood, liver, kidney) were also taken and stored at $4{ }^{\circ} \mathrm{C}$. Solid-phase extraction was performed using Amberlite XAD-2, polyaromatic adsorbent resin (Supelco; SIGMA ALDRICH, Taufkirchen, Germany).
The GC/MS drug analysis was performed using a Shimadzu GC-2010 with ion trap mass spectrometer (mass selective detector, MSD). The chromatographic column was RTX-5MS (5\% diphenyl-95 \% dimethyl polysiloxane, length $30 \mathrm{~m}$, diameter $0.25 \mathrm{~mm}$, film thickness $0.25 \mu \mathrm{m}$ ). The initial column temperature of $90{ }^{\circ} \mathrm{C}$ was held for $3 \mathrm{~min}$, then programmed to rise to $270{ }^{\circ} \mathrm{C}$ at $20^{\circ} \mathrm{C} \mathrm{min}^{-1}$, and held for $25 \mathrm{~min}$. Ultra-pure grade helium was used as the carrier gas at a flow rate of about $1.5 \mathrm{ml} \mathrm{min}^{-1}$. Blood-alcohol concentration (BAC) was measured using a Shimadzu 2010 gas chromatograph with a headspace and flame ionization detector (FID). Ter-Butanol was used as standard solution.

\section{RESULTS AND DISCUSSION}

The toxicological analysis of human tissues, including blood, and of the maggots showed the presence of amphetamine in all samples (Figures 1 and 2). Blood alcohol concentration was $0.45 \mathrm{~g} \mathrm{~kg}^{-1}$ (Table 1).

Intoxication with a combination of amphetamine and alcohol was established as a contributive death factor.

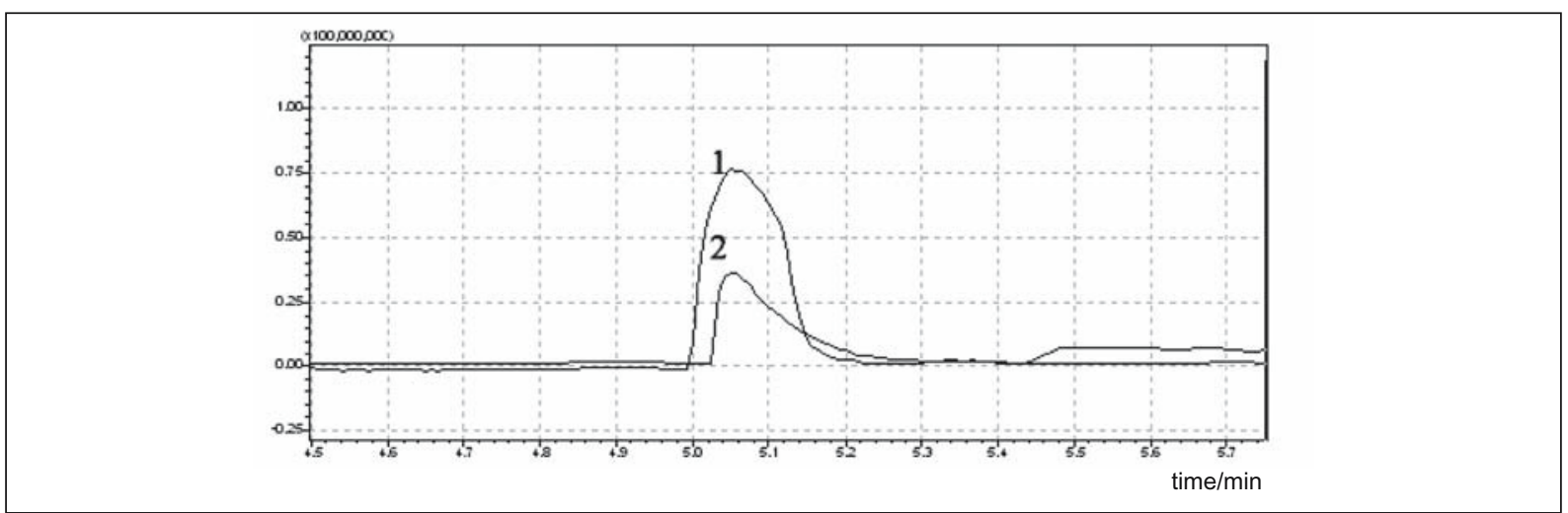

Figure 1 Total ion chromatogram of $5 \mathrm{~mL}$ blood (1) and larvae (2) after hydrolysis

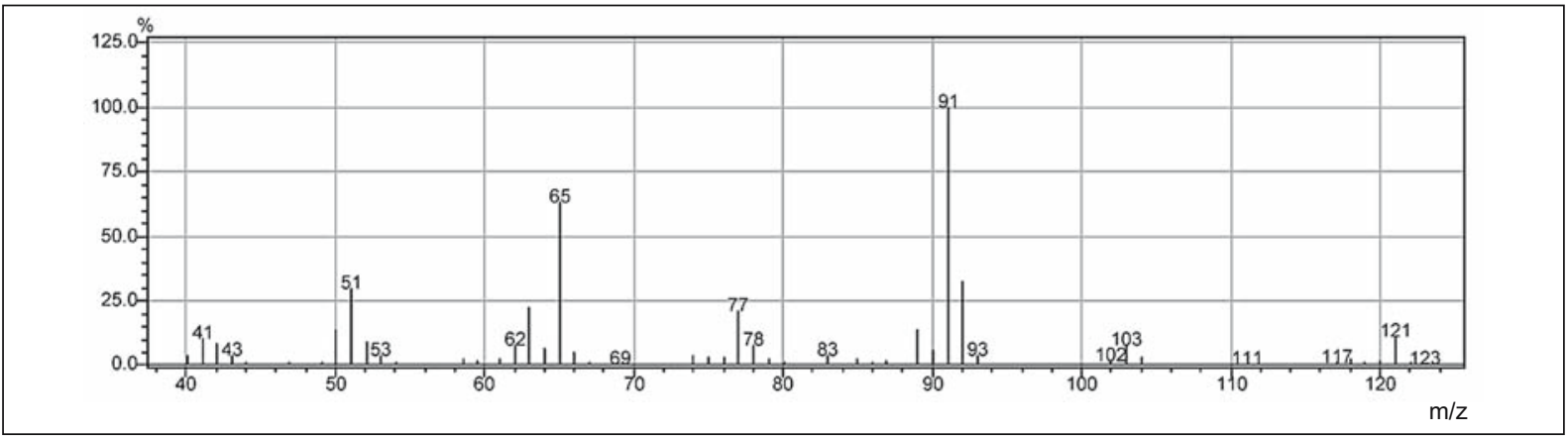

Figure 2 Characteristic mass spectra of Amphetamine in blood and larvae after hydrolysis 
Table 1 Organic compounds detected in analyzed samples

\begin{tabular}{lllll}
\hline Compound & Maggots & Blood & Liver & Kidney \\
\hline Amphetamine & + & $0.48 \mathrm{mg} \mathrm{L}^{-1}$ & $0.35 \mu \mathrm{g} \mathrm{g}^{-1}$ & $0.21 \mu \mathrm{g} \mathrm{g}^{-1}$ \\
Alcohol & - & $0.45 \mu \mathrm{g} \mathrm{g}^{-1}$ & - & - \\
\hline
\end{tabular}

+ Positive amphetamine finding

- Not measured

The concentrations of amphetamine in the human samples were below the fatal, and were significantly higher than those detected in blowfly larvae (maggots) found on human tissues. While the screening results were beyond doubt, quantitation was less clear. However, our findings correspond to those demonstrated in other studies where organic compounds, including amphetamine, were identified $(4,5,7)$. These studies found no correlation between drug concentrations in human material and larvae found on human corpses. This suggests that the accumulation of drugs in larvae is unpredictable and quantitation unreliable. Although there are researchers who are still sceptical about the usefulness of entomotoxicology in forensic medicine, we believe that all reasonable steps should be taken to perform a comprehensive toxicological analysis, if such is required to clear doubts related to a case $(4,5)$. We always have to keep in mind factors affecting toxicological analyses and the limitations of their interpretation. Maggots, even if used only for qualitative analysis, could play an important part in detecting drugs of abuse- and can contribute to establishing the cause, the manner and the mechanism of death.

\section{REFERENCES}

1. Goff ML. Estimation of postmortem interval using arthropod development and successional patterns. Forensic Sci Rev 1993;5:81-94.

2. Goff ML, Lord WD. Entomotoxicology: a new area for forensic investigation. Am J Forensic Med Pathol 1994;15:51-7.

3. Smith KGV. A manual of forensic entomology. Oxford: Cornell University Press; 1986.

4. Tracqui A, Keyser-Tracqui C, Kintz P, Ludes B. Entomotoxicology for the forensic toxicologist: much ado about nothing? Int J Legal Med 2004;118:194-6.

5. Campobasso CP, Gherardi M, Caligara M, Sironi L, Introna F. Drug analysis in blowfly larvae and in human tissues: a comparative study. Int $\mathrm{J}$ Legal Med 2004;118:210-4.

6. Kokan B, Definis-Gojanović $M$, Sutlović $D$, Milošević B. The forensic entomology method and general problems related to its introducing. In: Intona F, Campobasso CP, editors. Program and Abstracts of $4^{\text {th }}$ Meeting of European Association for Forensic Entomology; 26-29 April 2006; Bari, Italy. Bari: EAFE; 2006. p. 57.

7. Goff ML, Miller ML, Paulson JD, Lord WD, Richards E, Omori AI. Effects of 3,4methylenedioxymethamphetamine in decomposing tissues on the development of Parasarcophaga rucifornis (Diptera: Sarcophagidae) and detection of the drug in postmortem blood, liver tissue, larvae, and puparia. J Forensic Sci 1997;42:1212-3. 


\section{Sažetak}

\section{ANALIZA DROGA U NEKROFILNIM MUHAMA I LUUDSKIM TKIVIMA}

Insekti strvinari mogu pružiti korisne informacije o vremenu, mjestu i uzroku smrti. Dodatno, oni mogu poslužiti kao pouzdani zamjenski uzorci za toksikološke analize u slučajevima kada ljudska tkiva i tekućine, koji se uobičajeno uzimaju tijekom obdukcije, ne postoje zbog raspadanja trupla. Ovaj rad prikazuje rezultate analize droga u uzorcima ličinki dviju porodica muha (Diptera: Calliphoridae i Sarcophagidae), prikupljenima s tijela muškarca srednje životne dobi koji je počinio samoubojstvo otprilike 3 tjedna prije pronalaska njegova mrtvog tijela. Višestruki uzorci raspadajućeg ljudskog tkiva i ličinki muha analizirani su uporabom plinske kromatografije uz detekciju spektrometrijom masa (GC/MS) i u svima su otkriveni amfetamini. Dok su rezultati preliminarne kvalitativne analize bili izvan svake sumnje, kvantitativni su rezultati bili manje jasni te se preporučuje daljnje istraživanje u ovom području.

KLJUČNE RIJEČI: amfetamini, entomotoksikologija, GC/MS, sudska medicina

\section{CORRESPONDING AUTHOR:}

\section{Marija Definis-Gojanović, MD}

Department of Forensic Medicine

Split University Hospital and School of Medicine

Spinčićeva 1, 21000 Split, Croatia

E-mail:marija.definis-gojanovic@st.t-com.hr 